\title{
World market of liquid biofuels: trends, policy and challenges
}

\author{
Yevhenii Hyrchenko ${ }^{1}$, Tetiana Skibina ${ }^{2}$, Yana $\mathrm{Us}^{3}$, and Regina Veckalne ${ }^{4}$ \\ ${ }^{1}$ Sumy State University, International Economic Relations Department, 2 Rymskogo-Korsakova Str., Sumy, 40000, Ukraine \\ ${ }^{2}$ Kherson Economy and Law Institute, Department of Finance and Credit, 130 Krimskay Str., Kherson, 73028, Ukraine \\ ${ }^{3}$ Sumy State University, Department of Marketing, 2 Rymskogo-Korsakova Str., Sumy, 40000, Ukraine \\ ${ }^{4}$ Riga Technical University, The Institute of Building Entrepreneurship and Real Estate Economics, 1 Kalku str., Riga, LV-1658, Latvia
}

\begin{abstract}
This paper aimed at studying the current state of development of liquid biofuels' world market. The authors considered the theoretical bases of liquid biofuels production, their types, disadvantages and advantages. The world experience of introducing stimulation mechanisms of development and their influence on the sectors' growth is analyzed. In this study's frame, there is outlined the world leaders in the production of liquid biofuels. The findings represent the peculiarities of state regulation in implementing mandates for creating transport fuels with bioliquids. The current state of investment in the production of liquid biofuels was investigated. The obtained results contribute to the prospects for promoting world production of liquid biofuels to achieve the Paris Agreement's goals by 2030 under the sustainable development scenario.
\end{abstract}

\section{Introduction}

At the present stage of human development, most countries' main driver of economic growth is fossil energy resources. In turn, it negatively impacts the ecosystem. Therefore, the world community faces the problem to find energy resources, which will compromise the rate of economic growth and its impact on the environment. One of the promising areas aimed at reducing the anthropogenic impact is developing biomass potential for energy purposes. As the transport sector is one of the largest emitters of greenhouse gases, greening the industry is becoming increasingly crucial for the world. Given the current state of development of technologies related to the transport sector, the most promising direction to increase transport decarbonization may be liquid biofuels.

For Ukraine, the problem of liquid biofuels development has a special place because, despite the significant development of the agro-industrial sector, the market of liquid biofuels is in its infancy. Therefore, for implementing effective mechanisms to stimulate the growth of liquid biofuel production in the country, it is necessary to study current trends in the global biofuel market and analyze the experience of public policy created in countries that occupy leading positions in the market.

The article aims to study the main aspects of the world biofuel market development, determine the world leaders in biofuel production, and analyze the experience in creating a state biofuel policy. The paper provides an investigation on the development trend of world production of liquid biofuels.
Besides, there is an assessment of the prospects for achieving the Paris Agreement's goals by 2030 under the SDS (sustainable development scenario).

\section{Theoretical bases of producing liquid biofuels from biomass}

The modern branch of bioenergy offers the production of fuel for internal combustion engines based on raw materials of plant origin (liquid biofuel) [1,2], animal origin [2,3], organic waste (biogas) [3,4]. However, the use of liquid biofuels by the transport sector has become the most popular among the various types of renewable energy sources due to the convenience of the production process and higher energy density [5]. It stands to mention that liquid biofuels are usually producing by fermenting sugars (corn grains, sugar cane, etc.). That results in ethanol or by processing oilseeds such as rapeseed, soybean or palm oil into biodiesel.

Replacing biofuel, a traditional petroleum-based transport fuel, has several advantages. First, the production of biofuels helps to increase the country's energy security, reducing oil imports. Second, the use of bioliquids for transport helps reduce greenhouse gas (GHG) emissions [6]. Third, the production and use of liquid motor biofuels contribute to agricultural development, job creation and the filling of local budgets.

Note, the economic feasibility of liquid biofuel production directly depends on the choice of raw materials. When choosing a raw material base, it is necessary to consider the following [7]:

1. Crop capacity. This indicator is significant because the land resources used to grow energy crops are limited. For example, the yield of ethanol per acre is 462 gallons

\footnotetext{
* Corresponding author: ye.hyrchenko@uabs.sumdu.edu.ua
} 
per acre of 165 bushels of corn. Approximately 35 tons of crop or about 560 gallons of ethanol can be obtained from a sugar cane hectare [8]. Therefore, it is advisable to use land resources efficiently and prefer raw materials with the highest yields.

2. The need for nutrients. Growing raw materials for the production of liquid biofuels should not require large amounts of fertilizers. In addition to nutrients, there is a need for water resources. Indeed, nowadays, water is a valuable and scarce resource, so growing plants must require a moderate amount of water.

3. Growing conditions. Finding useful raw materials is closely related to the country's climatic conditions. Thus, it is advisable to grow energy crops that are best adapted to a particular country's climatic conditions.

It worth noting that nowadays, there are three generations of liquid biofuels as follows:

1. Biofuel of the 1st generation. This category includes fuels such as bioethanol, biodiesel, etc. First-generation biofuel production technologies are not new in the modern world. Approximately $2 \%$ of the world's arable land is used to produce such biofuels. However, the commercial competitiveness of the 1 st generation biofuels remains low compared to fossil fuels generally. The main difference characterizing the first generation of biofuels lies in the fact that it is producing from sugar and starchrich plants, oilseeds and animal fats. Alternatively, the raw material could be used for food purposes [9].

2. Biofuel of the 2 nd generation. This category includes biofuels made from non-edible raw materials and lignocellulosic biomass. Biofuel of the 2 nd generation is considered to be advanced technology in the modern world. The development of second-generation biofuels could address using land for growing bioenergy crops [9].

3. Biofuel of the $3 \mathrm{rd}$ generation. This category includes biofuels produced from algae. The main advantage of this technology is the lack of need to attract agricultural land and use raw materials that could be used for food purposes. However, this technology is quite expensive. Therefore, it would not be able to compete commercially with other technologies for biofuels soon [10].

It stands to mention that the use of liquid biofuels has both advantages and disadvantages. Table 1 systematized the main of them.

Table 1. The main advantages and disadvantages of using liquid motor biofuels (based on $[10,11,12]$ ).

\begin{tabular}{|c|c|c|}
\hline & Advantages & Disadvantages \\
\hline 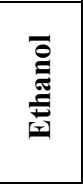 & $\begin{array}{l}\text { The use of bioethanol reduces the emissions of carbon } \\
\text { monoxide released by the vehicle's exhaust gases. Besides, } \\
\text { bioethanol impurities to gasoline allow obtaining a fuel } \\
\text { mixture with an increased octane number, which reduces fuel } \\
\text { consumption. }\end{array}$ & $\begin{array}{l}\text { The consumption of bioethanol in the engine power supply is } \\
\text { by } 51 \% \text { higher than gasoline consumption. For using bioethanol } \\
\text { in higher concentrations, modifications have to be made to the } \\
\text { internal combustion engine. }\end{array}$ \\
\hline 产 & $\begin{array}{l}\text { Compared to ethanol, butanol can be mixed in higher } \\
\text { proportions with gasoline. Besides, biobutanol has the property } \\
\text { of less solubility in water, less volatility and more excellent } \\
\text { safety. Thus, it allows for transporting fuel through existing } \\
\text { piping systems. The use of biobutanol in its pure form does not } \\
\text { require additional modifications to the engine. }\end{array}$ & $\begin{array}{l}\text { The process of biobutanol production is quite complicated and } \\
\text { lengthy. Moreover, the production of biobutanol is low } \\
\text { profitable and requires significant investment. }\end{array}$ \\
\hline 竞 & $\begin{array}{l}\text { Biomethanol production has significant economic advantages } \\
\text { over the production of other liquid biofuels. In comparison } \\
\text { with gasoline use, powering of the engine with fuel from a } \\
\text { gasoline mix with impurity of methanol reduces emissions of } \\
\text { harmful substances in the atmosphere. }\end{array}$ & $\begin{array}{l}\text { The consumption of biomethanol in the engine power supply is } \\
\text { greater than the consumption of gasoline. Besides, the use of } \\
\text { biomethanol by the vehicle contributes to corrosion processes } \\
\text { in the fuel system. Biomethanol requires special attention from } \\
\text { the car owner because it is toxic. Moreover, it poses a potential } \\
\text { danger to the human body. }\end{array}$ \\
\hline 焉国 & $\begin{array}{l}\text { The use of biodiesel fatty acid methyl ester (FAME) allows } \\
\text { significantly reduce emissions of harmful compounds and } \\
\text { particulate matter during engine operation compared to } \\
\text { traditional diesel. At the same time, biodiesel has good } \\
\text { lubricating properties, which allows increasing the engine's } \\
\text { service life. }\end{array}$ & $\begin{array}{l}\text { The use of biodiesel to power the engine in winter requires } \\
\text { additional compounds because the fuel begins to thicken at low } \\
\text { temperatures. Biodiesel is more aggressive against polymer and } \\
\text { rubber engine parts than gasoline. }\end{array}$ \\
\hline 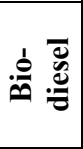 & $\begin{array}{l}\text { The use of HVO (hydrotreated vegetable oil) biodiesel reduces } \\
\text { NOx, PM and CO } 2 \text { emissions compared to traditional diesel } \\
\text { fuel. Compared to biodiesel, FAME has a longer shelf life and } \\
\text { higher energy content. }\end{array}$ & $\begin{array}{l}\text { The price of fuel is relatively high. Therefore, it is impossible } \\
\text { to compete with traditional diesel fuel. Limited feedstock when } \\
\text { using only vegetable oil. }\end{array}$ \\
\hline 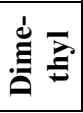 & $\begin{array}{l}\text { Proportional performance and efficiency with diesel fuel } \\
\text { having a high cetane number and low particulate emissio }\end{array}$ & $\begin{array}{l}\text { Compared to diesel fuel, it has less heat of combustion and } \\
\text { kinematic viscosity. Besides, DME is a strong solvent, so it } \\
\text { destroys rubber products }\end{array}$ \\
\hline
\end{tabular}

\section{The world trends in the liquid biofuels sector development}

Nowadays, the liquid biofuel sector is showing high growth rates. Currently, a large number of countries declare strategic goals for the development of the biofuel sector.

However, despite increased energy efficiency, an increase in the number of electric vehicles, and a steady increase in biofuel consumption persists transport as the industry with the lowest share of renewable energy sources $[1,13]$. Thus, liquid biofuels provide only about 
$3 \%$ ) of the world's fuel needs in the transport sector (Fig. $1)$.

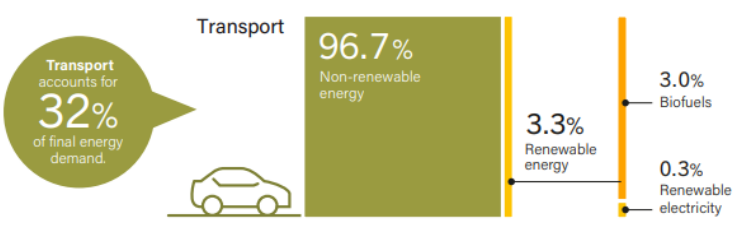

Fig. 1. The share of renewable energy in the total final energy consumption of the transport sector (based on [15]).

Nowadays, the production and use of biofuels such as biodiesel and bioethanol are the most widespread in of liquid biofuels market. Besides, approximately $65 \%$ of total world production is ethanol, and almost $35 \%-$ biodiesel [14].

Nowadays, the United States, Brazil, the EU and AsiaPacific are the world leaders in liquid biofuels production (Fig. 2). However, the undisputed leaders who provide more than half of liquid biofuels' world production are the United States and Brazil.

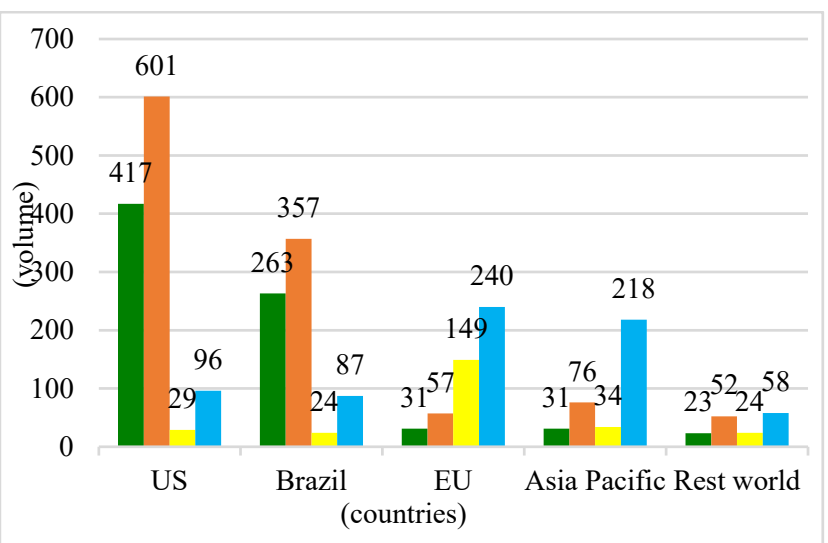

- Ethanol 2009 Ethanol 2019 Biodiesel 2009 Biodiesel 2019

Fig. 2. Biofuels production (thousand barrels of oil equivalent per day) (based on [14]).

The United States and Brazil provided more than $80 \%$ of world bioethanol production in 2019. It worth noting that these countries had been holding their leading positions in the bioethanol market for more than ten years. In turn, biodiesel production technology has gained the most popularity in the EU. Herewith, the EU had been in the lead for over ten years. It stands to mention that the rapid growth in biodiesel production occurred in AsiaPacific, where production increased by six times over the past decade [14].

The world market for liquid biofuels has an annual growth rate of 3\% (54 thousand barrels of oil equivalent per day), while in the last decade, the growth rate was two times higher [14].

In general, biodiesel production is experiencing higher industry growth than ethanol ( $13 \%$ vs $2 \%$ relatively). Thus, Indonesia demonstrated a rapid increase in biodiesel production (7\%) [14].

It could be assumed that the global liquid biofuels sector has been growing for more than a decade. However, the growth rate has slowed significantly.
Besides, biodiesel production, which is confidently increasing its share in the global fuel and energy sector structure, is gaining popularity. In turn, the Asia-Pacific countries show a significant contribution to the worldwide growth of liquid biofuels. These countries consider the industry as an effective mechanism for disposing of agricultural residues and increasing energy sovereignty.

\section{Energy policies to promote sector of liquid biofuels development}

Figure 3 demonstrates that implementing an effective strategy for developing the industry at the national level results in the liquid biofuel sector's positive effect. However, there is still a lack of a comprehensive strategy for decarbonizing transport in many countries. Besides, policies to promote renewable energy in the transport sector continue to focus mainly on road transport, which accounts for the vast majority of energy use in the transport sector, while ignoring aviation and shipping.

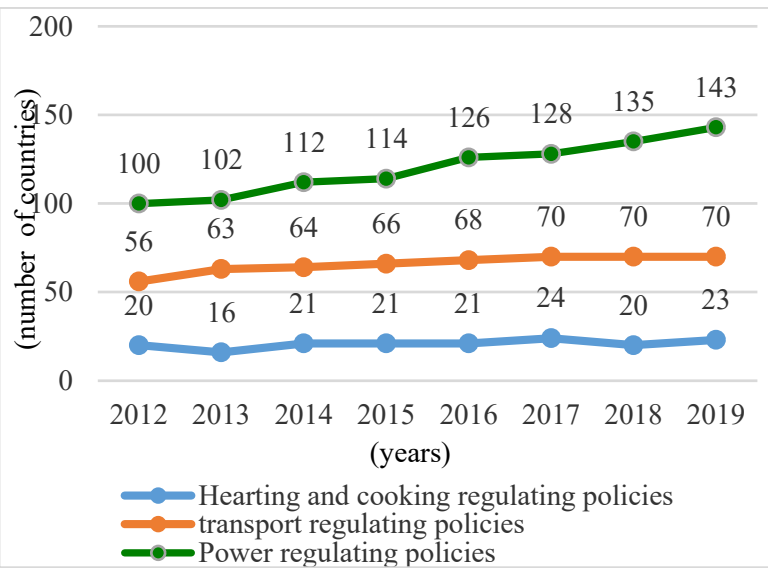

Fig. 3. Number of countries implementing Renewable Energy Policies (2012-2019) (based on [15]).

Policies for support biofuels' production and using include blending mandates, financial incentives, public procurement, and infrastructure support for refuelling and blending. Herewith, mandates for blending biofuels are the most widely accepted type of policy to increase renewable fuels in the transport sector, common in all regions and countries

Table 2 demonstrates that the number of countries with the authority to mix biofuels has recently remained stable (70 countries in 2019). However, mandates for blending are not always fulfilled.

The trend of stimulating the development of liquid biofuels' production and using the mandate to create fuel mixtures has recently gained popularity in many countries due to the increase in the mandate to create fuel mixtures. However, the most significant changes took place in Indonesia (from B20 in 2018 to B30 in 2019), Brazil (where the blending standard increased from B10 to B11 in 2019; besides, the country approved the sale and use of B15) and France (where agreed with an increase in the mandate for mixing bioliquids from 7.9 to 8.2 in 2020) [15]. 
According to Ren 21, the global biofuel market demonstrates the growing popularity of advanced biofuels. In 2019, the EU and eight other countries had mandates to mix advanced biofuels, while 24 countries were preparing to introduce such mechanisms [15].

Table 2. Biofuels Global Production in 2019 (Top-10 countries and EU-28) (based on [15,16]).

\begin{tabular}{|c|c|c|c|c|c|}
\hline \multirow{3}{*}{ Country } & \multirow{2}{*}{ Ethanol } & \multirow{2}{*}{\begin{tabular}{|c|} 
Biodiesel \\
(Fame)
\end{tabular}} & \multicolumn{3}{|c|}{ Blend Mandate } \\
\hline & & & \multirow{2}{*}{ Ethanol } & \multirow{2}{*}{ Biodiesel } & \multirow{2}{*}{$\begin{array}{c}\text { Advanced } \\
\text { biofuel }\end{array}$} \\
\hline & \multicolumn{2}{|c|}{ Billion litres } & & & \\
\hline USA & 59,7 & 4,0 & E2-E20 & B2-B10 & - \\
\hline Brazil & 35,3 & 5,9 & E27 & B11 & - \\
\hline Indonesia & 0 & 7,9 & E3 & B30 & - \\
\hline China & 4,0 & 0,6 & E10 & - & - \\
\hline Germany & 0,8 & 3,8 & - & - & $\begin{array}{c}0.05 \% \\
\text { from } 2020 \\
\text { (for fuel } \\
\text { suppliers } \\
\text { supplying } \\
\text { at least } 20 \\
\mathrm{PJ} / \mathrm{a} \text { ). }\end{array}$ \\
\hline France & 0,9 & 2,8 & $\begin{array}{r}7.9 \% \mathrm{~b} \\
\text { motc }\end{array}$ & $\begin{array}{l}\text { iofuels in } \\
\text { or fuel }\end{array}$ & $\begin{array}{c}2.3 \% \text { of } \\
\text { diesel and } \\
3.4 \% \text { of } \\
\text { petrol from } \\
\text { advanced } \\
\text { biofuels by } \\
2023 \\
\end{array}$ \\
\hline Argentina & 1,1 & 2,5 & E12 & $\mathrm{B} 10$ & - \\
\hline Thailand & 1,6 & 1,7 & E5 & B7 & $\begin{array}{c}25 \text { million } \\
\text { litres per } \\
\text { day by } \\
2022\end{array}$ \\
\hline Spain & 0,5 & 2 & Ove & arall 6 & $\begin{array}{c}0.1 \% \text { from } \\
2020\end{array}$ \\
\hline EU-28 & 4,7 & 12,4 & - & - & $\begin{array}{c}0.2 \% \text { by } \\
2022,1 \% \\
\text { by } 2025 ; \\
3.5 \% \text { by } \\
2030\end{array}$ \\
\hline
\end{tabular}

Table 2 shows the leaders of world production of liquid biofuels. The assessment of the structure of national policies of mandates for mixing reflects the industry trend and the prospect of further changes in the construction of fuel consumption by the transport sector. However, liquid biofuel producers' success is due to the introduction and other individual mechanisms to stimulate the production and consumption of liquid biofuels, consider the most significant of them, for individual leaders in the global biofuel market (Table 3).

The total amount of investment in liquid biofuels production decreased in the last decade, while RE's investment income almost doubled (Fig. 4). This fact explains the slowdown in sectoral growth in biofuel production and the shallow renewable energy level used in the global transport sector.

Despite the low level of investment support in the industry, there is still a significant increase in investment activity for some types of biofuels. Recently, increasing investor attention has focused on advanced biofuels technology, including HVO.
Table 3. The policy of the state stimulating the development of liquid biofuel production and its efficiency (based on [17,18]).

\begin{tabular}{|c|c|c|}
\hline $\begin{array}{l}\text { Co- } \\
\text { unt- } \\
\text { ry }\end{array}$ & Public policy & Efficiency \\
\hline$\underset{\infty}{\stackrel{\infty}{\sigma}}$ & $\begin{array}{l}\text { The loan guarantee program is } \\
\text { designed to support new inno- } \\
\text { vative bioenergy facilities. Se- } \\
\text { veral programs have been cre- } \\
\text { ated at the federal level that } \\
\text { encourage increased produc- } \\
\text { tion, biofuels, and the deve- } \\
\text { lopment of biomass supply lo- } \\
\text { gistics. }\end{array}$ & $\begin{array}{l}\text { The United States provi- } \\
\text { des } 50 \% \text { of world produc- } \\
\text { tion of ethanol and } 14 \% \text { of } \\
\text { biodiesel. Over the last de- } \\
\text { cade, many experimental, } \\
\text { demonstration, and com- } \\
\text { mercial projects of } 2 \text { nd ge- } \\
\text { neration biofuels have } \\
\text { emerged. }\end{array}$ \\
\hline 氕 & $\begin{array}{l}\text { Tax benefits for producers and } \\
\text { users of liquid biofuels. } \\
\text { The quota for duty-free im- } \\
\text { ports of ethanol is } 600 \text { million } \\
\text { litres per year. } \\
\text { Providing subsidies for produ- } \\
\text { cers of raw materials used in } \\
\text { the process of biofuel produc- } \\
\text { tion. } \\
\text { Financial incentives for the } \\
\text { development of } 2 \text { nd generati- } \\
\text { on biofuel production. }\end{array}$ & $\begin{array}{l}\text { Brazil provides } 26 \% \text { of the } \\
\text { world production of etha- } \\
\text { nol and } 12 \% \text { of biodiesel. } \\
\text { Two commercial and one } \\
\text { demonstration plant for } \\
\text { cellulose ethanol producti- } \\
\text { on has been established. } \\
\text { The possibility of joint } \\
\text { processing of crude oil } \\
\text { and vegetable oils is acti- } \\
\text { vely studied. }\end{array}$ \\
\hline 䒿 & $\begin{array}{l}\text { Producers of ethanol from } \\
\text { non-food crops have the op- } \\
\text { portunity to receive tax bene- } \\
\text { fits in the form of exemption } \\
\text { from excise duty and VAT. } \\
\text { Discounts on VAT for expor- } \\
\text { ters of ethanol and biodiesel. } \\
\text { The government provides a } \\
\text { subsidy of } \$ 0.07 \text { per litre for } \\
\text { cellulosic ethanol producers. } \\
\text { China focuses on ethanol pro- } \\
\text { duction. }\end{array}$ & $\begin{array}{l}\text { In 2019, China produced } \\
4 \text { bln litres of ethanol and } \\
\text { ranked third in the world } \\
\text { in terms of ethanol pro- } \\
\text { duction and consumption. } \\
\text { The ethanol producers' } \\
\text { support scheme often de- } \\
\text { pends on the country's } \\
\text { grain stocks. } \\
\text { The use and production of } \\
\text { biodiesel in the country is } \\
0.2 \% \text { of diesel fuel volu- } \\
\text { me. }\end{array}$ \\
\hline 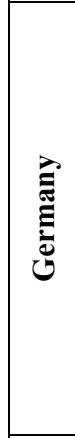 & $\begin{array}{l}\text { Various types of funding } \\
\text { programs focus primarily on } \\
\text { stimulating the production of } \\
\text { advanced biofuels and, to a } \\
\text { lesser extent, conventional } \\
\text { biofuels. For example, "ener- } \\
\text { gy transition in the transport } \\
\text { sector" no longer any unique } \\
\text { counting of biofuels mecha- } \\
\text { nism included in the national } \\
\text { legislation. }\end{array}$ & $\begin{array}{l}\text { In average, since } 2007 \text {, et- } \\
\text { hanol's total production } \\
\text { and use have grown annu- } \\
\text { ally by } 10-12 \% \text {, while an- } \\
\text { nual biodiesel production } \\
\text { remains relatively unchan- } \\
\text { ged. } \\
\text { Several demonstration re- } \\
\text { search projects aimed at } \\
\text { the production of advan- } \\
\text { ced biofuels have been } \\
\text { created. }\end{array}$ \\
\hline & $\begin{array}{l}\text { The import of biofuels is ban- } \\
\text { ned. However, it is allowed } \\
\text { for importing raw materials } \\
\text { for biofuel production. } \\
\text { State support aimed at stimu- } \\
\text { lating the production of } 2 \text { nd } \\
\text { generation biofuels. } \\
\text { Biofuel policy provides per- } \\
\text { mission for foreign direct in- } \\
\text { vestment in the biofuel facili- } \\
\text { ty's equity in the amount of } \\
100 \% \text {. }\end{array}$ & $\begin{array}{l}\text { The current share of biofu- } \\
\text { els in India's transport se- } \\
\text { ctor is approximately } \\
1.2 \% \text {. } \\
\text { The percentage of mixing } \\
\text { ethanol with gasoline is } \\
2 \% \text {, biodiesel - } 0.1 \% \text {. } \\
\text { The effectiveness of state } \\
\text { policy on the development } \\
\text { of liquid biofuels is low. } \\
\text { The main limiting factor } \\
\text { in developing the liquid } \\
\text { biofuels market is the lack } \\
\text { of the required volume of } \\
\text { raw materials. }\end{array}$ \\
\hline
\end{tabular}




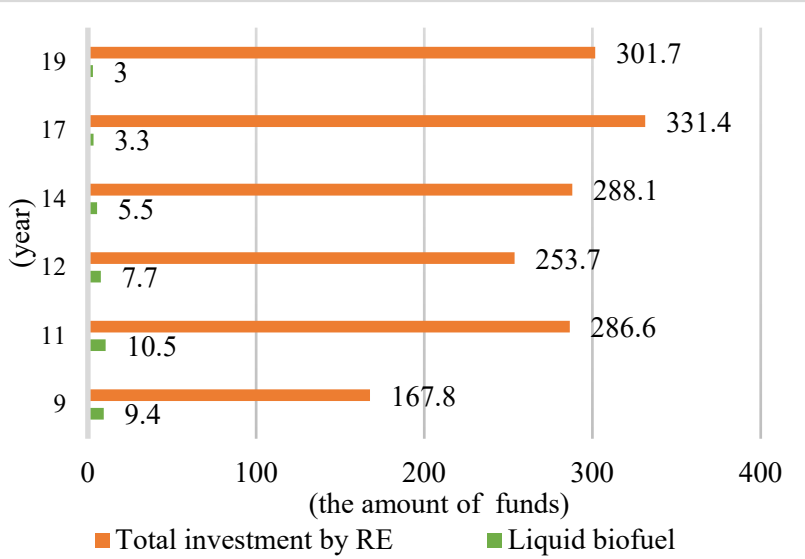

Fig. 4. New Investments by Technology, bln USD, (20092019) (based on [11]).

The growth of investment attention to the HVO is primarily due to a significant increase in demand for biofuels from heavy goods vehicles and aviation. According to REN 21, if the planned HVO projects are successfully implemented, the industry's global production capacity will triple to 22 bln litres annually.

It is worth noting that despite the prevalence of investor attention to HVO technology, this industry provides only $6 \%$ of biofuels, while biodiesel FAME $35 \%$.

\section{Paris Agreement and perspectives biofuels}

The modern world market of liquid biofuels characterized by the dominant role of production and consumption of 1st generation biofuels; however, the need to produce new generation liquid biofuels are multiplying.

According to the International Energy Agency (IEA) forecasts, liquid biofuel production's growth rate would be $3 \%$ in the next five years. Simultaneously, to achieve the Paris Agreement's goals, the minimum amount of sectoral growth should be $10 \%$ by 2030 . To comply with the SDS (sustainable development scenario aimed at achieving the goals set out in the Paris Agreement), world production and consumption of liquid biofuels should increase by three times by 2030 (to 298 Mtoe). However, given the current pace of biofuel production, most countries would not reach the required level provided for in the SDS (Fig. 5). It is also necessary to increase the pace of development of advanced biofuel consumption and the adoption of biofuels in aviation and marine transport to achieve these goals. Only sustainable biofuels have a place in the SDS [20].

The main limiting factor that slows down the global transport sector's greening is the lack of strong political support and insufficient development of technological innovations that would help reduce the cost of production of advanced biofuel.

Biofuel production in the US and EU countries lags far behind SDS rates. The increase in demand for biofuels in these countries is due to fuel mixtures containing bioliquids. Therefore, given the tendency to increase the efficiency of vehicles, and as a consequence, the decrease in fuel demand, the rate of increase in biofuel production does not change significantly. However, if countries change their market regulation policies to increase mandatory mandates for blending fuels, the share of liquid biofuels in the country's fuel and energy sector could grow[20].

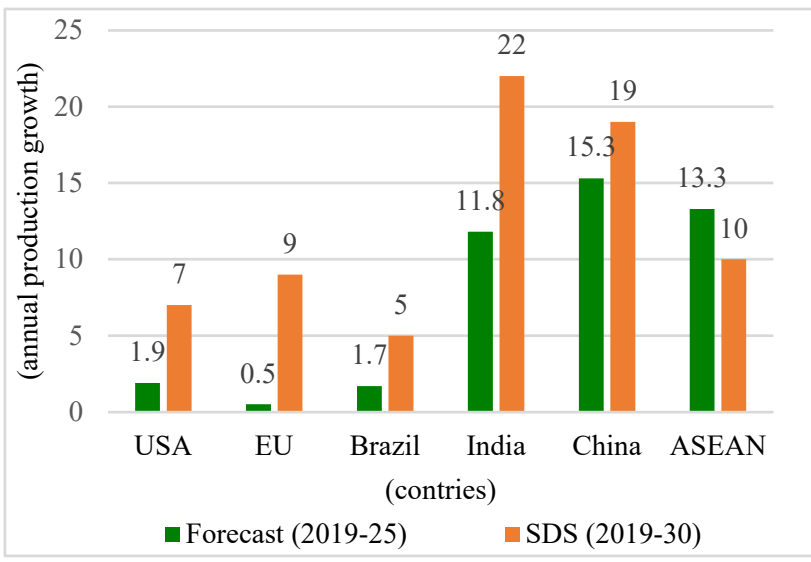

Figure 5. Prospect for key biofuel markets (\% of growth) (based on [18])

In turn, Brazil is already one of the leading producers of biofuels. The country is also increasing its mandate for blending fuel mixtures and is actively increasing production capacity for ethanol production. However, according to IEA forecasts, the government would not achieve a pace of sectoral growth to meet the SDS goals [20].

Given the current state of biofuel production in India, the country would not achieve the SDS goals. However, recently the production of biofuels in the country is actively growing. The government also introduced a new regulatory policy in 2018. This policy expanded the authorization to use different types of raw materials that could be used for ethanol production. Moreover, it provided subsidies aimed at expanding production capacity for ethanol production. However, it stands to mention that the country focuses only on ethanol production[20].

In turn, China and the ASEAN countries could reach the SDS level while maintaining the current growth rate. China is actively increasing new production capacity for ethanol production and plans to introduce the E10 standard in 10-15 provinces.

It worth emphasizing that the main barrier that slows down the global transport sector's greening is the lack of strong political support and insufficient development of technological innovations that would help reduce the cost of production of advanced biofuel [20].

Recently, researchers have paid more attention to the introduction of Euro 7 (for cars) and VII (for heavy). The new Euro 7 emission standard is to enter into force in the EU in 2025. The planned Euro-7 standard provides for clear emission standards for vehicles from 2025. Thus, new vehicles will emit only $30 \mathrm{mg}$ of NOx (nitrous oxide) per kilometre, and in the second scenario - only $10 \mathrm{mg}$ per kilometre. The current limit is $60 \mathrm{mg}$ for gasoline and 80 $\mathrm{mg}$ for diesel cars. Besides, CO2 limits should be sharply reduced to 300 or $100 \mathrm{mg}$, depending on the car category 
[21]. The adoption of relevant legislation is expected to increase the transport sector's transition rate to the use of low-carbon and sustainable renewable fuels [22]. New realities open up great opportunities for the liquid biofuel industry, in particular new generation biofuels.

\section{Conclusion}

Several advantages of liquid motor biofuels produced from bioenergy raw materials testify to the prospect of their production against the background of depletion of oil reserves and global environmental challenges.

World production of liquid biofuels is growing every year, gaining more and more supporters among different countries. The global biofuel market is competitive and fragmented, with several well-known international players. The last trends of the leading countries in the organizational and economic mechanisms on stimulating the liquid biofuel industry indicate the prevalence of state support, namely in the production of advanced biofuels.

By regional segmentation, the global biofuel market can grow in North and South America, Europe, Asia Pacific (APAC), the Middle East and Africa (MEA). According to forecasts, North America will hold a leading position in the global market for liquid biofuels. Besides, high growth rates of liquid biofuel production will be observed in the EU, China, the United States and Brazil.

The obtained results showed that the level of investment in biofuel production remains relatively low. Therefore, it makes the transport sector one of the largest greenhouse gas emitters. The forecast on the industry's development and the assessment of the possibility to achieve the Paris Agreement goals indicates that most countries would not achieve the required levels of liquid biofuels production by 2030 .

\section{References}

1. N. Scovronick, P. Wilkinson, Global Environmental Change 24, 155-164 (2014). doi:10.1016/j.gloenvcha.2013.09.011

2. T. Kurbatova, Economic benefits for producers of biogas from cattle manure within energy cooperatives in Ukraine, International Journal of Sustainable Energy Planning and Management 18, 69-80 (2018). doi:10.5278/ijsepm.2018.18.5

3. T. Kurbatova, Ye. Hyrchenko, Energy co-ops as a driver for bio-energy sector growth in Ukraine, in IEEE 3rd International Conference on Intelligent Energy and Power Systems (IEPS), Kharkiv, September 10-14, P. 210-213 (2018). doi:10.1109/IEPS.2018.8559516

4. J. Ammenberg, S. Anderberg, T. Lönnqvist, S. Grönkvist, T. Sandberg, Resources, Conservation and Recycling 129, 70-80 (2018). doi:10.1016/j.resconrec.2017.10.010

5. Biogas a renewable biofuels, UF (2019). https://biogas.ifas.ufl.edu/biogasdefs.asp. Accessed 21 Mar 2021
6. P. Moriarty, X. Yan, S. Wang, Energy Procedia 158, 3265-3270

(2020). doi:10.1016/j.egypro.2019.01.986

7. Biotoplivo: Perspektivy, Riski i Vozmozhnosti. http://www.fao.org/3/a-i0100r.pdf (2020)

8. Bioenergy corn, CROPWATCH https://cropwatch.unl.edu/bioenergy/corn (2020)

9. P. Morone, L. Cottoni, Biofuels, Handbook of Biofuels Production, pp. 61-83 (2016). doi:10.1016/b978-0-08-100455-5.00004-7

10. Y. Dahman, C. Dignan, A. Fiayaz, A. Chaudhry, Biomass, Biopolymer-Based Materials, and Bioenergy, pp. 241-276 (2019). doi:10.1016/b978-008-102426-3.00013-8

11. S.Saha, A.Sharma, S.Purkayastha, K.Pandey, S.Dhingra, Plastics to Energy, pp. 365-376 (2019). http://doi:10.1016/b978-0-12-813140-4.00014-5

12. Certas Energy. https://certasenergy.co.uk/news/mybusiness/alternative-fuels-the-pros-and-cons/ (2020)

13. T.Kurbatova, T.Perederii, Global trends in renewable energy development, in IEEE KhPI Week on Advanced Technology, October 5-10, 2020, Kharkiv, pp. 260-263. doi:10.1109/KhPIWeek51551.2020.9250098

14. Renewable energy, British Petroleum. https://www.bp.com/en/global/corporate/energyeconomics/statistical-review-of-worldenergy/renewable-energy.html (2020)

15. Renewables 2020, Global status report, REN 21, https:/www.ren21.net/wpcontent/uploads/2019/05/gsr_2020_full_report_en.p df (2020)

16. European renewable ethanol, ePURE. https://www.epure.org/wpcontent/uploads/2021/03/210310-REV4-MEMO2021-National-biofuels-policies-March-update.pdf (2018)

17. M. Ebadian, S. van Dyk, J. McMillan, J. Saddler, Energy Policy 147, $111906 \quad$ (2020). http://doi:10.1016/j.enpol.2020.111906

18. A. Saravanan, A. Pugazhendhi, T. Mathimani, Fuel 272 (2020). doi:10.1016/j.fuel.2020.117635

19. C.-Y. Lin, C. Lu, Renewable and Sustainable Energy Reviews 136, $110445 \quad$ (2021). doi:10.1016/j.rser.2020.110445

20. IEA. https://www.iea.org/reports/transportbiofuels\#tracking-progress (2020)

21. No to the Euro 7 emissions standard, FOUNDRY DAILY NEWS. https://www.foundryplanet.com/d/no-to-the-euro-7-emissions-standard/ (2021)

22. Legislation for sustainable mobility, AECC. https://www.aecc.eu/legislation-for-sustainablemobility/ (2020) 